\title{
Characterization of the low-pH responses of Helicobacter pylori using genomic DNA arrays
}

\author{
Elaine Allan, ${ }^{1}$ Christopher L. Clayton, ${ }^{2}$ Alistair McLaren, ${ }^{2}$ \\ Donald M. Wallace ${ }^{2}$ and Brendan W. Wren ${ }^{1}$
}

Author for correspondence: Brendan W. Wren. Tel: +44 207927 2288. Fax: +44 2076368739.

e-mail: brendan.wren@1shtm.ac.uk

\begin{abstract}
1 Pathogen Molecular Biology and Biochemistry Unit, Department of Infectious and Tropical Diseases, London School of Hygiene and Tropical Medicine, Keppel Street, London WC1E 7HT, UK

2 Department of Genomics, Glaxo Wellcome Medicines Research Centre, Gunnels Wood Road, Stevenage, Hertfordshire SG1 2NY, UK
\end{abstract}

\begin{abstract}
Helicobacter pylori is unique among bacterial pathogens in its ability to persist in the acidic environment of the human stomach. To identify $H$. pylori genes responsive to low $\mathrm{pH}$, the authors assembled a high-density array of PCRamplified random genomic DNA. Hybridization of radiolabelled CDNA probes, prepared using total RNA from bacteria exposed to buffer at either pH 4.0 or pH 7.0, allowed both qualitative and quantitative information on differential gene expression to be obtained. A previously described low-pH-induced gene, cagA, was identified together with several novel genes that may have relevance to the survival and persistence of $H$. pylori in the gastric environment. These include genes encoding enzymes involved in LPS and phospholipid synthesis and secF, encoding a component of the protein export machinery. A hypothetical protein unique to $H$. pylori (HP0681) was also found to be acid induced. Genes down-regulated at pH 4.0 include those encoding a sugar nucleotide biosynthesis protein, a flagellar protein and an outermembrane protein. Differential gene expression was confirmed by total RNA slot-blot hybridization.
\end{abstract}

Keywords: acid-induced gene expression, genomic DNA array, pathogenicity

\section{INTRODUCTION}

Helicobacter pylori is unique among bacterial pathogens in that it can persist in the acidic environment of the human stomach. Although most of the H. pylori population in the stomach is found in the mucous layer close to the gastric epithelial cell surface where the $\mathrm{pH}$ is thought to be neutral (Thomsen et al., 1990), the bacterium is able to tolerate extreme acidity in the gastric lumen following ingestion and is likely to encounter gastric acid periodically during the course of infection. H. pylori produces large quantities of urease, which neutralizes the acidic environment locally around the organism by hydrolysis of urea to ammonia. In vitro, urease is required for survival at $\mathrm{pH} 4.0$ and below, whereas at higher acidic $\mathrm{pH}$, mechanisms independent of urease are protective (see McGowan et al., 1996). Further evidence of other specialized acid defence mechanisms is provided by the existence of ureasepositive, acid-sensitive mutants (Bijlsma et al., 1998).

To investigate these urease-independent mechanisms, McGowan and co-workers used subtractive RNA hybridization and identified a gene which was induced at $\mathrm{pH} 4.0$ and involved in LPS $\mathrm{O}$-antigen biosynthesis.
Mutation of this gene resulted in increased acid sensitivity, suggesting that structural changes to LPS may be an important acid-induced adaptation (McGowan et al., 1998). Proteome analysis of $H$. pylori has shown that decreasing the $\mathrm{pH}$ of the growth medium from $\mathrm{pH} 7 \cdot 0$ to $5 \cdot 0$ reduces the amount of $\mathrm{VacA}$ and HtrA, a vacuolating cytotoxin and a serine protease, respectively, possibly as a result of increased secretion of these proteins (Jungblut et al., 2000).

Other acid-induced genes of $H$. pylori include $\operatorname{cag} A$, encoding the cytotoxin-associated protein of unknown function, which is induced at $\mathrm{pH}$ 6.0 (Karita et al., 1996), and HSP70 (DnaK), induced and surface-expressed following brief exposure to $\mathrm{pH} 2 \cdot 0$. Induction of HSP70 results in a change in host receptor binding specificity and this may provide a survival advantage at low $\mathrm{pH}$ (Huesca et al., 1998).

The aim of our study was to identify genes differentially expressed following exposure to $\mathrm{pH} 4.0$ that may potentially have a role in the pathogenesis of infection. To achieve this we assembled a high-density array of PCR-amplified random genomic DNA derived from a library of strain NCTC 11637 (Clayton et al., 1995). 
Radiolabelled cDNA probes were prepared from total RNA of bacteria exposed to either $\mathrm{pH} 4.0$ or $\mathrm{pH} 7.0$ and hybridized to the genomic DNA array. This system, used previously to study competence gene expression in Streptococcus pneumoniae (Rimini et al., 2000), allowed us to identify $H$. pylori genes which are up- and downregulated in response to an acidic environment. Amongst the differentially expressed genes identified by array hybridization, those having a possible role in pathogenesis were further investigated by total RNA slot-blot hybridization to confirm induction or repression by low $\mathrm{pH}$.

\section{METHODS}

Bacterial strains and culture conditions. H. pylori strain 26695 (Tomb et al., 1997) was grown on Helicobacter selective agar, consisting of Blood Agar Base no. 2 (Oxoid) supplemented with $7 \%$ lysed defibrinated horse blood (SigmaAldrich) and Dent's selective supplement (Oxoid) in a microaerobic atmosphere at $37^{\circ} \mathrm{C}$. A microaerobic atmosphere was generated either by using a CampyGen sachet (Oxoid) in a gas pack jar or by incubation in an incubator equilibrated with $10 \% \quad \mathrm{CO}_{2}, 85 \% \quad \mathrm{~N}_{2}$ and $5 \% \mathrm{O}_{2}$. For exposure to low $\mathrm{pH}$, strain 26695 was inoculated from $48 \mathrm{~h}$ agar cultures into brain heart infusion (BHI) broth (Oxoid) containing $10 \%$ fetal calf serum, and incubated overnight on a rotary shaker $(150$ r.p.m.) in a microaerobic atmosphere at $37^{\circ} \mathrm{C}$.

RNA preparation. To isolate total RNA from bacteria exposed to low pH, H. pylori 26695 was incubated for 30 min either in citrate buffer at $\mathrm{pH} 4.0$ or in phosphate-buffered saline $(\mathrm{pH} 7 \cdot 0)$. Bacterial cells were harvested by centrifugation at 4000 r.p.m. for $10 \mathrm{~min}$ at $20^{\circ} \mathrm{C}$, and total RNA purified using the Ribolyser-Blue kit (Hybaid). The quality of the RNA was evaluated on $0.7 \%$ non-denaturing agarose gels and concentration determined by absorbance at $260 \mathrm{~nm}$. Genomic DNA was eliminated by digestion with DNase I (Life Technologies) and this was confirmed by $u r e B$-specific primer PCR (Table 1), sensitive to DNA concentrations of $1 \mathrm{pg}$.

Preparation of complex cDNA probe. Radiolabelled singlestranded cDNA was prepared by reverse transcription of total RNA isolated from bacteria exposed to either $\mathrm{pH} 4.0$ or $\mathrm{pH} 7 \cdot 0$. The reaction, which consisted of $12.5 \mu \mathrm{g}$ total RNA, 5 ng random hexamers (Amersham Pharmacia), $5 \mu \mathrm{l}\left[{ }^{33} \mathrm{P}\right] \mathrm{dCTP}$ [3000 Ci mmol ${ }^{-1}\left(111 \mathrm{TBq} \mathrm{mmol}^{-1}\right)$; Amersham Pharmacia], $2 \cdot 5 \mu \mathrm{l} 0.1 \mathrm{M}$ dithiothreitol, $1.25 \mu \mathrm{l}$ of a mixture of $1 \mathrm{mM}$ dATP, dGTP, dTTP and $0.01 \mathrm{mM}$ dCTP, $10 \mathrm{U}$ RNase inhibitor (Boehringer Mannheim) and $250 \mathrm{U}$ SuperScript II reverse transcriptase (Life Technologies), in a total volume of $25 \mu \mathrm{l}$, was incubated at $42{ }^{\circ} \mathrm{C}$ for $90 \mathrm{~min}$. Following inactivation of reverse transcriptase, $\mathrm{cDNA}$ probes were purified using Sephadex G-50 spin columns (Amersham Pharmacia). To examine the quality and length of complex probes, aliquots of each probe were analysed on $6 \%$ polyacrylamide-TBE gels (Novex Electrophoresis) and visualized using a Molecular Dynamics phosphor imager (Storm 860, Amersham Pharmacia). To prevent masking of neighbouring spots by rRNA and tRNA hybridization, $30 \mu \mathrm{g}$ each of unlabelled Escherichia coli $16 \mathrm{~S} 23 \mathrm{~S}$ rRNA and tRNA (Sigma-Aldrich) was added to the probes to block hybridization to RNA clones on the array. A luciferase cDNA probe was prepared by oligo$\mathrm{dT}$ priming using $1 \mu \mathrm{g}$ luciferase mRNA (Promega) and Superscript II reverse transcriptase (Life Technologies) as previously described (Kittler et al., 2000).
Preparation of high-density genomic DNA array. A pBluescript genomic library of H. pylori NCTC 11637 (consisting of 3354 clones of mean insert size $1 \cdot 0 \mathrm{~kb}$ ) (Clayton et al., 1995) was used as template for 96-well PCR amplification using Taq polymerase (Perkin Elmer), $P f u$ polymerase (Stratagene) and M13 forward and reverse primers (Amersham Pharmacia) in $50 \mu$ containing $0.2 \mathrm{mM}$ dNTPs, and $1 \times$ Promega PCR buffer. The M13 forward and reverse primers which flank a T7 primer binding site were selected in order to amplify a common segment of vector DNA from each clone. The PCR consisted of 30 cycles of $1 \mathrm{~min}$ of denaturation at $94{ }^{\circ} \mathrm{C}, 30 \mathrm{~s}$ of annealing at $50{ }^{\circ} \mathrm{C}$, and $2 \mathrm{~min}$ of extension at $72{ }^{\circ} \mathrm{C}$. One column from each 96 -well plate was analysed by agarose gel electrophoresis to determine the success rate of amplification. Products were transferred to 384-well plates and arrayed in duplicate onto positively charged $11 \times 15 \mathrm{~cm}$ nylon membranes (Boehringer Mannheim) using an automated 384-pin gridding device (Genetix Q-bot). The 384-well plates containing the PCR products were retained for sequencing. The membranes were denatured $(0.5 \mathrm{M} \mathrm{NaOH}$, $100 \mathrm{mM} \mathrm{NaCl}$ ), neutralized ( $1 \mathrm{M}$ Tris $\mathrm{pH} 7 \cdot 2,100 \mathrm{mM} \mathrm{NaCl}$ ) and UV cross-linked using a Stratalinker (Stratagene). The luciferase gene of Coleoptera was amplified by PCR and gridded at determined positions on the array to allow orientation of the hybridized image. To determine the variability of robotic arraying of PCR products, duplicate arrays were hybridized with a T7 oligonucleotide probe internal to the PCR products. These experiments showed that there was less than $5 \%$ variation in the amount of DNA spotted at a particular coordinate between duplicate arrays.

End-labelling of T7 oligonucleotide with $\left[\gamma-{ }^{33} \mathrm{P}\right] \mathrm{dATP}$. T7 primer (40 pmol; Amersham Pharmacia) was end-labelled with $\left[\gamma_{-}{ }^{33} \mathrm{P}\right] \mathrm{dATP}$ in a $50 \mu \mathrm{l}$ reaction containing $5 \mu \mathrm{l}[\gamma$ ${ }^{33} \mathrm{P}$ ]dATP $\left(3000 \mathrm{Ci} \mathrm{mmol}^{-1} ; 111 \mathrm{TBq} \mathrm{mmol}^{-1}\right.$ ) and $20 \mathrm{U}$ polynucleotide kinase (New England Biolabs). The reaction was incubated at $37^{\circ} \mathrm{C}$ for $1 \mathrm{~h}$ and unincorporated nucleotides removed using Sephadex G25 spin columns (Amersham Pharmacia).

Hybridization. Six copies of the genomic DNA array were generated: four for duplicate hybridizations with the $\mathrm{pH} 4 \cdot 0$ and $\mathrm{pH} 7 \cdot 0$ cDNA probes, and two for duplicate hybridizations with a T7 oligonucleotide probe internal to all PCR products in order to determine the relative amounts of DNA present on the array. Prehybridization and hybridization were carried out at $45^{\circ} \mathrm{C}$ in DIG Easy Hyb solution (Boehringer Mannheim) in a rotisserie oven. Prehybridization was carried out for a minimum of $30 \mathrm{~min}$ and hybridization for $72 \mathrm{~h}$. Membranes hybridized with cDNA probes were washed three times for $15 \mathrm{~min}$ using $2 \times \mathrm{SSC}, 0 \cdot 1 \%$ SDS at $60^{\circ} \mathrm{C}$. Membranes hybridized with the T7 oligonucleotide were washed three times for 15 min with $6 \times$ SSC, $0.5 \%$ SDS at $45{ }^{\circ} \mathrm{C}$. All membranes were exposed to a phosphor storage screen for $48 \mathrm{~h}$ and image data were captured on the Molecular Dynamics phosphor imager.

Image analysis. Image data files were analysed and compared using the Glaxo Wellcome proprietary DGENT software package. The median spot intensity of each image was used to normalize for differences in specific activity between probes. Only spots showing at least a $1 \cdot 3$-fold difference in hybridization intensity between the $\mathrm{pH} 4.0$ and $\mathrm{pH} 7 \cdot 0 \mathrm{cDNA}$ probes and no significant difference between $\mathrm{T} 7$ oligonucleotide hybridization intensities were reported. In addition, only differential hybridizing spots showing a minimum $95 \%$ consistency between duplicates were considered significant.

Identification of differentially expressed spots. Differentially expressed spots were identified by sequencing of the cor- 
Table 1. Oligonucleotide PCR primers

\begin{tabular}{|c|c|c|}
\hline Primer & Sequence $\left(5^{\prime}-3^{\prime}\right)$ & $\begin{array}{c}\text { Target gene TIGR HP } \\
\text { no.* }\end{array}$ \\
\hline EA20F & ATGAAAAAGATTAGCAGAAAAGAA & ureB, НP0072 \\
\hline EA20R & CTAGAAAATGCTAAAGAGTTGCGC & ureB, НР0072 \\
\hline EA41F2 & TTGAAAGAGTTTGCTTATAG & НР0366 \\
\hline EA41R2 & СTCTCAAAAGTTTTTAAAACGC & НР0366 \\
\hline EA42F & ACGAAAGAGAACTTGAATGGC & НР0681 \\
\hline EA42R & CACССССАTTTAGCGCAAAGC & НР0681 \\
\hline EA43F & TTAAGATCTCTGTGGATAACG & HP1052 \\
\hline EA43R & TTAACCAACATGGAATTGAGC & HP1052 \\
\hline HP1459F & CAAGCACTCCAGAAGAGAGGC & HP1459 \\
\hline HP1459R & GCAACTCATTGTATTCTTGGC & HP1459 \\
\hline EA46F & ACAAATATGATAGAGACTTGG & HP1588 \\
\hline EA46R & CGACTTCTTATCTCCATTGGC & HP1588 \\
\hline EA50F & TAAAGATCCGAATGTGTTGCG & НР0871 \\
\hline EA50R & ATAAGACAAAGGAGTTATCGC & НР0871 \\
\hline $\mathrm{RC} 5 \mathrm{~F}$ & ATTATTCAAACGAACTAG & HP1549 \\
\hline RC5R & ACTTGACCGCTCTATAC & HP1549 \\
\hline EA60F & ACGCCGCGTGGAGGATG & $16 \mathrm{~S}$ rRNA \\
\hline EA60R & GCTCCCCACGCTTTCGC & $16 \mathrm{~S}$ rRNA \\
\hline
\end{tabular}

*Refers to the genome sequence of H. pylori 26695 (Tomb et al., 1997); TIGR, The Institute for Genomic Research.

responding PCR product and subsequent database searches using BLAST tools (Altschul et al., 1997). Sequencing was performed with T7 or T3 primers (Amersham Pharmacia) using a BigDye Terminator Cycle Sequencing Ready Reaction kit (Perkin Elmer) as recommended by the supplier. Samples were analysed on an ABI model 377 automated sequencer.

RNA slot-blot hybridizations. For confirmation of differential gene expression by slot-blot hybridization, independent RNA samples were prepared as described above. Samples $(5-10 \mu \mathrm{g})$ of total RNA were mixed with 3 vols denaturation solution and heated at $65^{\circ} \mathrm{C}$ for $15 \mathrm{~min}$. After cooling on ice, 2 vols icecold $20 \times$ SSC was added and samples applied to Hybond-N (Amersham Pharmacia) using a slot-blot filtration manifold (Amersham Pharmacia). Membranes were pre-wet in $10 \times$ SSC and slots washed with $0.5 \mathrm{ml} 10 \times$ SSC before and after addition of sample. Membranes were blotted dry and baked at $80{ }^{\circ} \mathrm{C}$ for $2 \mathrm{~h}$. DNA probes were generated by PCR using primers (Table 1) based on DNA sequences obtained from the TIGR website (http://www.tigr.org/tdb/CMR/ghp/htmls/ SplashPage.html). Probes were labelled with $\left[\alpha^{32} \mathrm{P}\right] \mathrm{dCTP}$ (3000 Ci mmol ${ }^{-1}$; $111 \mathrm{TBq} \mathrm{mmol}^{-1}$ ) using a Rediprime random prime labelling kit (Amersham Pharmacia) and hybridized with the blots at $42^{\circ} \mathrm{C}$ for $16 \mathrm{~h}$ in buffer containing formamide (AMS Biotechnology). Membranes were washed twice with $2 \times$ SSC, $0 \cdot 1 \%$ SDS at $42{ }^{\circ} \mathrm{C}$ and then with $0 \cdot 1 \times$ SSC, $0 \cdot 1 \%$ SDS at $55^{\circ} \mathrm{C}$ and analysed using the Molecular Dynamics phosphor imager.

\section{RESULTS}

\section{Construction of the $\boldsymbol{H}$. pylori genomic DNA array}

In order to generate a $H$. pylori array, a pBluescript genomic DNA library of strain NCTC 11637 consisting of 3354 clones with a mean insert size of $1.0 \mathrm{~kb}$ (Clayton et al., 1995) was amplified by 96-well PCR using vector- specific primers. This library was selected because the $1.0 \mathrm{~kb}$ inserts correspond approximately to the size of a H. pylori ORF (Tomb et al., 1997). Agarose gel electrophoresis of one column from each 96-well plate indicated that approximately $81 \%$ of the amplifications were successful. As the $H$. pylori genome is $1.67 \mathrm{Mb}$, the generated array was expected to provide approximately $1 \cdot 6$-fold coverage of the genome. A series of hybridizations of duplicate arrays with a T7 oligonucleotide probe internal to each PCR product showed that there was at least $95 \%$ consistency between arrays in the amount of PCR product spotted.

\section{Genes up-regulated at low pH}

An image showing genomic DNA arrays hybridized with $\mathrm{pH} 4.0$ and $\mathrm{pH} 7 \cdot 0$ cDNA probes and analysed using proprietary software is shown in Fig. 1. Comparison of the hybridization patterns of the $\mathrm{pH} 4.0$ and $\mathrm{pH} 7 \cdot 0$ cDNA probes identified 25 clones showing an increase in signal intensity of $1 \cdot 3-2 \cdot 2$ fold with the $\mathrm{pH} 4.0$ probe compared to the $\mathrm{pH} 7 \cdot 0$ probe. Analysis of duplicate arrays hybridized with the T7 oligonucleotide showed that these differences were not due to differences in the quantity of DNA. The PCR-amplified genomic DNA fragments corresponding to these 25 clones were recovered from the stored 384-well plates and sequenced. Four PCR products failed to give meaningful sequence information and were not progressed further. Since a PCR-amplified random genomic DNA library was used for array construction, it was possible to have multiple detections of the same clone. BLAST analysis of the sequences of the 21 remaining PCR products showed 
(a)

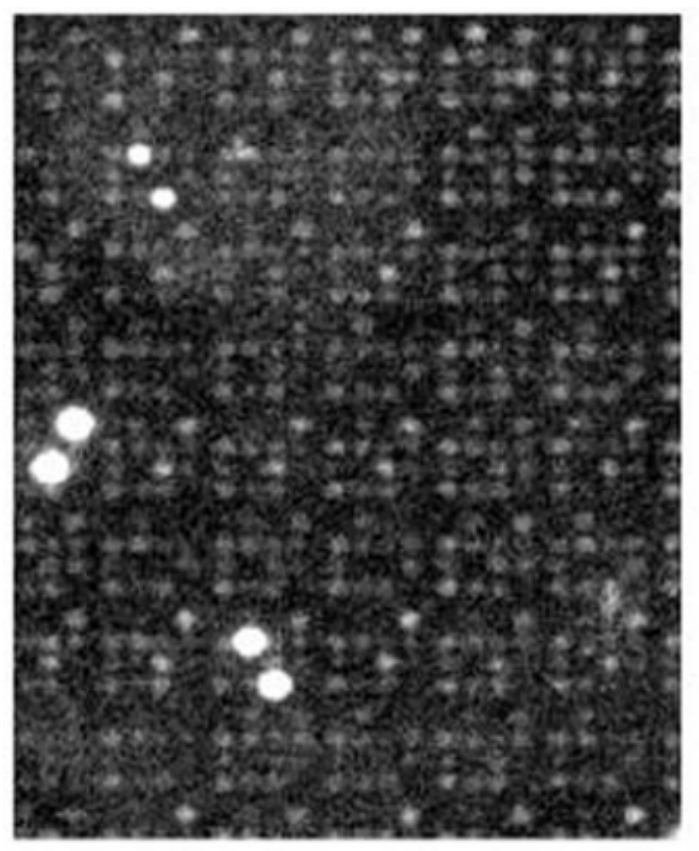

(b)

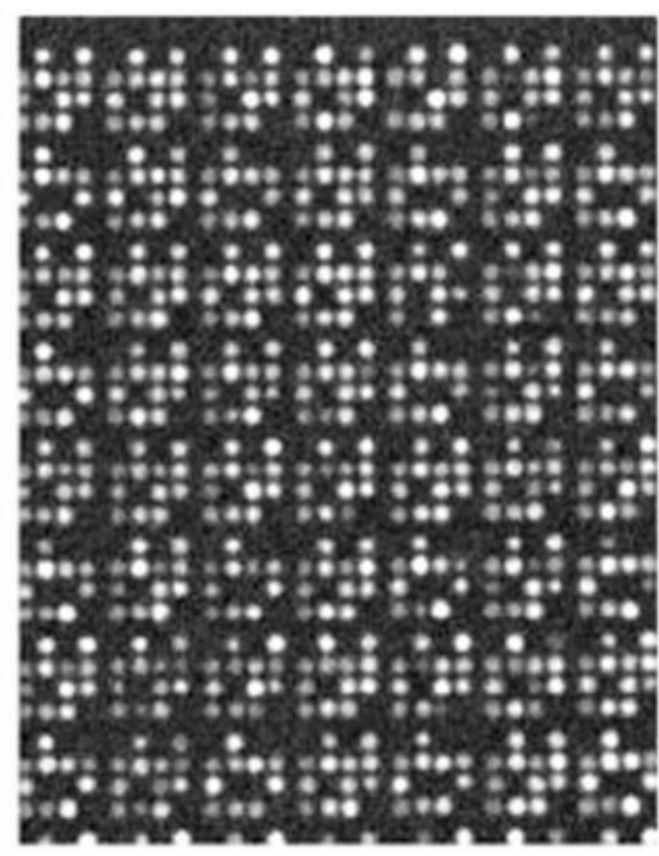

Fig. 1. Close-up images of duplicate genomic DNA arrays hybridized with (a) complex cDNA probe derived from pH $4 \cdot 0$ RNA and (b) T7 oligonucleotide probe. The intense hybridizing spots in (a) contain rRNA genes.

that four genes were represented more than once (three genes were present in duplicate PCR products and one gene in triplicate). One PCR product contained the known acid-induced gene cagA (Karita et al., 1996). As our primary interest is bacterial pathogenesis, of the 16 remaining genes we chose to confirm acid-induction of only those genes we considered likely to play a role in the pathogenesis of $H$. pylori infection. The inclusion or exclusion of putative acid-induced genes from further analysis was based primarily on sequence similarity between the H. pylori gene product and known pathogenicity factors present in the databases. Total RNA slot-blot hybridizations were performed using PCRamplified DNA probes for 11 of the 16 putative acidinduced genes. These hybridizations were carried out using fresh RNA samples isolated in independent low-pH exposure experiments. Analysis of these hybridizations confirmed $\mathrm{pH} 4 \cdot 0$-induced upregulation of 7 of the 11 genes tested. These genes are listed in Table 2.

HP0681, induced at least $2 \cdot 2$-fold at $\mathrm{pH} 4 \cdot 0$, is considered unique to $H$. pylori as it exhibits no similarity with sequences in the public databases. There is a paralogue of HP0681 present in both sequenced strains: HP1289 in strain 26695 (Tomb et al., 1997; Alm et al., 1999). These paralogues share $69 \%$ identity in a 157 amino acid overlap. Both HP0681 and HP1289 are preceded by members of another two-member paralogous family (HP0682 and HP1288), also unique to H. pylori and containing predicted $\mathrm{N}$-terminal signal peptides for Secdependent secretion (Tomb et al., 1997). The relatively short HP0681-0682 and HP1288-1289 intergenic distances suggests that these gene pairs may be cotranscribed.

HP1052, the expression of which is increased 1.6-fold at $\mathrm{pH} 4.0$ (Table 2), is an orthologue of envA $\left(l_{p x} \mathrm{C}\right)$ of $E$. coli encoding UDP-3-O-acyl $\mathrm{N}$-acetylglucosamine deacetylase. This enzyme, ubiquitous in Gram-negative bacteria, catalyses the second step of lipid A biosynthesis and is a point of regulation for LPS biosynthesis (Sorensen et al., 1996). Analysis of the predicted amino acid sequence of HP1052 using BLASTP (Altschul et al., 1997) identifies the putative UDP-3-O-acyl N-acetylglucosamine deacetylase of Campylobacter jejuni as the closest match, with $54 \%$ identity in a 294 amino acid overlap. The predicted $H$. pylori enzyme shares $34 \%$ identity (in a 297 amino acid overlap) with its counterpart in Escherichia coli. The transcript level of HP0871, encoding CDP-diacylglycerol pyrophosphatase, is also increased at $\mathrm{pH} 4 \cdot 0$. This enzyme is involved in synthesis of phospholipids which are components essential for the structure and function of bacterial membranes.

Two enzymes concerned with ribonucleotide biosynthesis and modification are also upregulated at pH 4.0 (HP1459, HP0919). HP1459 encodes an orthologue of C. jejuni pseudouridine synthase, required for synthesis of the modified ribonucleotide, pseudouridine, in large-subunit rRNA. The HP0919 gene product shows significant similarity with the carbamoylphosphate synthase enzyme of C. jejuni involved in the biosynthesis of pyrimidine ribonucleotides. 
Table 2. Genes up- or down-regulated at $\mathrm{pH} 4 \cdot 0$, closest orthologue, and putative function

\begin{tabular}{|c|c|c|c|c|c|c|c|}
\hline \multicolumn{2}{|c|}{ Gene no. in strain } & \multirow{2}{*}{$\begin{array}{l}\text { Description of } \mathrm{H} \text {. pylori gene product or closest } \\
\text { orthologue (E-value from BLASTX analysis) }\end{array}$} & \multirow[t]{2}{*}{ Organism } & \multirow[t]{2}{*}{ Function/other information } & \multirow{2}{*}{$\begin{array}{l}\text { Accession } \\
\text { no. } \neq\end{array}$} & \multicolumn{2}{|c|}{ Induction ratio } \\
\hline $26695^{*}$ & $\mathrm{~J} 99+$ & & & & & 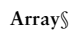 & Slot-blot $\|$ \\
\hline \multicolumn{8}{|c|}{ Up-regulated } \\
\hline 0681 & 0622 & Hypothetical $19 \cdot 2 \mathrm{kDa}$ protein $(0 \cdot 0)$ & H. pylori & Unknown function & A64605 & $2 \cdot 2$ & $4 \cdot 4$ \\
\hline 0919 & 0853 & Carbamoyl-phosphate synthase large chain $(0 \cdot 0)$ & C. jejuni & $\begin{array}{l}\text { Carbamoyl-phosphate synthase; pyrimidine } \\
\text { ribonucleotide biosynthesis }\end{array}$ & AL139074.2 & 1.9 & $1 \cdot 8$ \\
\hline 1588 & 1494 & Conserved hypothetical $28.4 \mathrm{kDa}$ protein $(9 \mathrm{e}-21)$ & E. coli & Unknown function; paralogues HP1587, 1589 & C64721 & $1 \cdot 8$ & $3 \cdot 2$ \\
\hline 1459 & 1352 & $\begin{array}{l}\text { Putative ribosomal pseudouridine synthase } \mathrm{b}(r \operatorname{lu} B) \\
(2 \mathrm{e}-68)\end{array}$ & C. jejuni & $\begin{array}{l}\text { Synthesis of pseudouridine from uracil in } 23 \mathrm{~S} \\
\text { rRNA }\end{array}$ & AL139079.2 & $1 \cdot 8$ & $1 \cdot 4$ \\
\hline 1052 & 0373 & $\begin{array}{l}\text { UDP-3-O-[3-hydroxymyristoyl] } \mathrm{N} \text {-acetylglucosamine } \\
\text { deacetylase }\left(l_{p} x C\right)(2 \mathrm{e}-91)\end{array}$ & C. jejuni & Lipid A biosynthesis & AL139074.2 & $1 \cdot 6$ & $1 \cdot 8$ \\
\hline 0871 & 0805 & CDP-diacylglycerol pyrophosphatase $(c d b)(1 \mathrm{e}-102)$ & E. coli & Phospholipid biosynthesis & P06282 & $1 \cdot 4$ & $1 \cdot 2$ \\
\hline 0547 & 0495 & $\begin{array}{l}\text { Cytotoxin-associated immunodominant antigen } \\
(\text { cagA) }(0.0)\end{array}$ & H. pylori & $\begin{array}{l}\text { Unknown function, located on cag } \\
\text { pathogenicity island }\end{array}$ & P55746 & $1 \cdot 4$ & ND \\
\hline 1549 & 1450 & $\begin{array}{l}\text { Probable protein-export membrane protein }(\sec F) \\
(8 \mathrm{e}-63)\end{array}$ & C. jejuni & Protein secretion & AL139077.2 & $1 \cdot 3$ & $2 \cdot 0$ \\
\hline \multicolumn{8}{|c|}{ Down-regulated } \\
\hline 0366 & 1015 & $\begin{array}{l}\text { Probable sugar nucleotide biosynthesis protein } \\
(7 \mathrm{e}-87)\end{array}$ & C. jejuni & ?Protein glycosylation & AL139078.2 & $-6 \cdot 2$ & $-3 \cdot 9$ \\
\hline 0753 & 0690 & Flagellar protein $(f l i S)(4 \mathrm{e}-39)$ & C. jejuni & ?Chaperone for flagellar export & AL139075.2 & $-2 \cdot 0$ & $-1 \cdot 2$ \\
\hline 0229 & 0214 & Outer-membrane protein $(b o p A)(0 \cdot 0)$ & H. pylori & Porin & E64548 & $-1 \cdot 9$ & $-2 \cdot 7$ \\
\hline
\end{tabular}

*According to the genome sequence of strain 26695 (HP prefixes omitted) (Tomb et al., 1997).

† According to the genome sequence of strain J99 (HP prefixes omitted) (Alm et al., 1999).

$\ddagger$ Accession numbers refer to the GenBank/EMBL, SWISS-PROT or PIR databases.

SInduction ratios expressed as maximum fold increase in hybridization intensity between duplicate spots on genomic DNA arrays hybridized with $\mathrm{pH} 4 \cdot 0 \mathrm{cDNA}$ probe compared to that hybridized with $\mathrm{pH} 7 \cdot 0 \mathrm{cDNA}$ probe.

$\|$ Induction ratios expressed as maximum fold increase in hybridization intensity between pH $4 \cdot 0$ and pH 7.0 total RNA slot-blots hybridized with gene-specific DNA probe; ND, not done.

Also identified as acid-induced was secF (HP1549), encoding a component of the cytoplasmic membrane protein secretion apparatus. This gene was induced 1.3fold at $\mathrm{pH} 4 \cdot 0$ compared to $\mathrm{pH} 7 \cdot 0$. SecF is one of six components of the Sec-dependent protein export pathway in E. coli. The H. pylori genome contains four of the six E. coli components (Tomb et al., 1997), together with orthologues of the two leader peptidases required in E. coli for cleavage of signal sequences from exported proteins. The short intergenic distance between $s e c F$ and secD in both sequenced strains of H. pylori (Tomb et al., 1997; Alm et al., 1999) suggests that, in common with $E$. coli, these genes may be co-transcribed. SecF and SecD are thought to act at a similar step in protein secretion but their precise function is unclear.

The other acid-induced gene identified in this study, HP1588, encodes a protein with an orthologue in E. coli, the function of which is unknown. Interestingly, this gene is a member of a paralogous family which includes the adjacent gene HP1587. In our array hybridizations, HP1587 was also identified as acid-induced and showed a similar induction ratio to that of HP1588, suggesting that these genes may be co-transcribed.

\section{Genes down-regulated at low pH}

Our analysis also identified 34 differentially hybridizing spots which showed significantly decreased signal intensity (1.4-6.2 fold) at $\mathrm{pH} 4 \cdot 0$ compared to $\mathrm{pH} 7 \cdot 0$. Sequence analysis of the $34 \mathrm{PCR}$-amplified genomic DNA fragments identified four encoding $23 \mathrm{~S}-5 \mathrm{~S}$ rRNA, indicating that addition of unlabelled rRNA to the probe had been only partially successful in blocking hybridization to rRNA clones. Of the 30 remaining PCR products, three genes were multiply represented. Taking into account this redundancy, we identified 14 genes putatively down-regulated at $\mathrm{pH} 4 \cdot 0$. Of the seven of these which were considered to have a likely role in pathogenesis and were tested by total RNA slot-blotting, three were confirmed using RNA extracted in independent low-pH experiments (Fig. 2, Table 2). The four other genes analysed by slot-blot hybridization showed no change in expression level at $\mathrm{pH} 4 \cdot 0$ (not shown).

The expression of HP0366, encoding a probable sugar nucleotide biosynthesis protein, is down-regulated at $\mathrm{pH} 4 \cdot 0$. The predicted amino acid sequence of this gene shows significant similarity to proteins involved in polysaccharide biosynthesis. Another orthologue, FlmB of Caulobacter crescentus, appears to be involved in the post-translational modification of flagellins, essential for proper assembly of the flagellar filament (Leclerc et al., 1998). Studies are under way to determine the function of HP0366 in H. pylori.

Two other genes were found to be down-regulated at pH 4.0: HP0753, encoding a flagellar protein, and HP0229, which encodes the HopA porin. This porin is a member of a closely related family of porins (HopA to HopD) whose precise function is unknown (Exner et al., 1995). Although a change in expression of an outermembrane protein in response to environmental conditions is not surprising given its proximity to the 
(a)
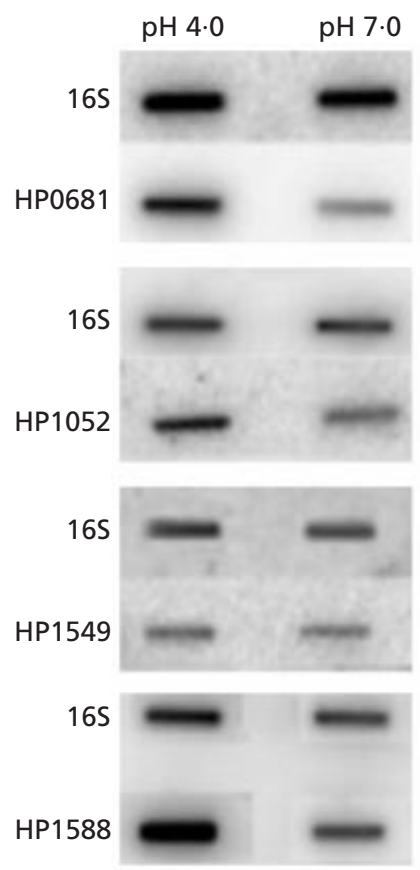

(b)
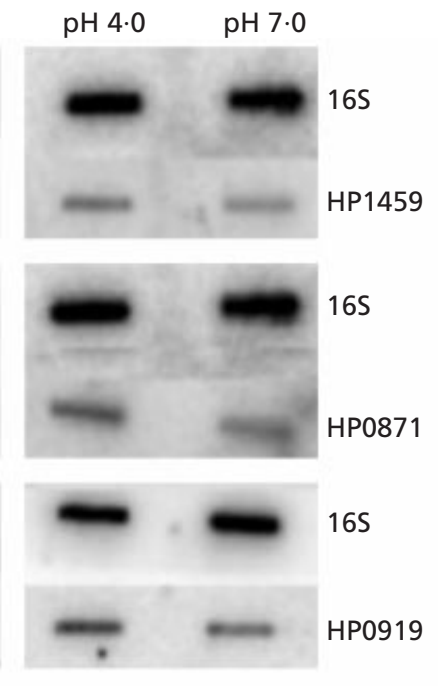

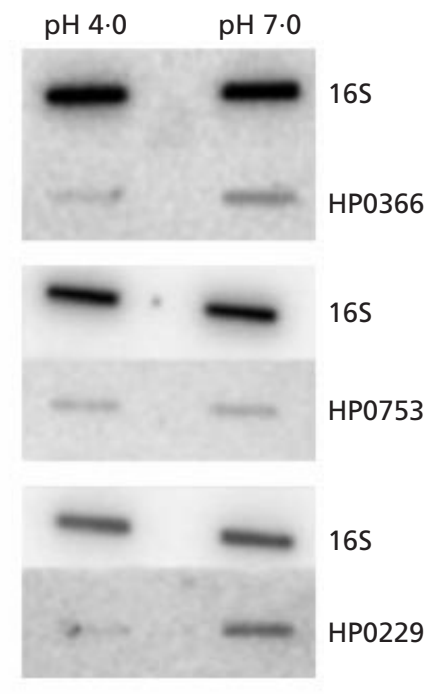

Fig. 2. Total RNA slot-blot hybridization of acid-responsive genes: (a) genes up-regulated at pH 4.0; (b) genes downregulated at $\mathrm{pH} 4 \cdot 0$.

external milieu, the effect of down-regulation of HopA on cell physiology requires further investigation.

\section{DISCUSSION}

By hybridization of total RNA-derived cDNA probes to a random genomic DNA array, we were able to identify genes of $H$. pylori differentially expressed at $\mathrm{pH} 4 \cdot 0$, compared to $\mathrm{pH} 7 \cdot 0$. To construct our array we used as template for PCR a random genomic library of $H$. pylori NCTC 11637. This library was constructed for an independent genome sequencing project before publication of the genome sequence of strain 26695 and it was our intention to use this resource to derive functional information.

Among the up-regulated genes detected in our experiment was $\operatorname{cag} A$, the immunodominant cytotoxinassociated gene, known to be inducible at acidic $\mathrm{pH}$ (Karita et al., 1996). Karita and co-workers reported a 1.7 -fold increase in $\operatorname{cag} A$ transcription at $\mathrm{pH} 6.0 \mathrm{com}$ pared to $\mathrm{pH} 7 \cdot 0$. We detected a similar increase in $\operatorname{cag} A$ transcription at $\mathrm{pH} 4 \cdot 0$.

Several other acid-inducible genes were identified, including those encoding proteins involved in the structure and synthesis of cell surface components (HP1052, HP0871) and enzymes involved in ribonucleotide biosynthesis and modification (HP0919, HP1459). Other novel acid-induced genes identified in this work include secF (HP1549), encoding a component of the protein secretion machinery, and HP0681, a gene unique to $H$. pylori.
The mRNA induction ratios we observed following exposure of $H$. pylori to $\mathrm{pH} 4 \cdot 0$ were relatively low compared to those reported in other studies of differential gene expression in bacteria. For example, a 20 -fold increase in transcription of one gene was observed during competence development in Streptococcus pneumoniae (Rimini et al., 2000), and induction ratios of several hundred fold were reported in a study of global gene expression in B. subtilis grown in anaerobic conditions (Ye et al., 2000). In our study, the fact that several of the genes showing low fold changes in gene expression using the array could be confirmed using conventional total RNA slot-blot hybridization demonstrates the sensitivity of our system. It should also be emphasized that the slot-blot hybridizations used RNA samples prepared in independent acid-exposure experiments, demonstrating that our data are reproducible. Our data also show that the in vitro response of $H$. pylori to $\mathrm{pH} 4 \cdot 0$ comprises a subtle change in the pattern of gene expression. These subtle changes may still be significant in vivo: the atrB gene of Salmonella enterica serovar Typhimurium, an essential component of the acid tolerance response, is induced only $1 \cdot 4$-fold at pH 5.8 in vitro (Foster \& Bearson, 1994).

Of the 18 putative acid-responsive genes identified in the array studies, eight failed to be confirmed by RNA slotblot hybridization. This may be due to the relatively low sensitivity of the Northern hybridization technique or because the genes concerned produce short-half-life mRNA not consistently isolated in all RNA samples. We used total RNA slot-blot hybridization as it is considered 
the standard for mRNA quantitation although a more sensitive method such as RT-PCR may have improved our confirmation rate.

For those genes which were confirmed as differentially expressed, the induction ratios determined by densitometric analysis of the slot-blot hybridizations correlated well in most cases with those calculated using the array. Quantitative differences were apparent, however, between the array and slot-blot data for some genes (e.g. HP0681, HP1588). This may result from the fact that independent RNA samples were used, perhaps reflecting slight differences in the exposure time between individual experiments. An alternative reason for the difference is that different probe types were used in the two experiments, an explanation given previously in studies where discrepancies of much greater magnitude (10-fold) were apparent, even between experiments using the same RNA sample (Rimini et al., 2000).

Our finding that the lipid A biosynthetic enzyme UDP-3$\mathrm{O}$-acyl $\mathrm{N}$-acetylglucosamine deacetylase (HP1052) is acid-induced is consistent with previously published data which demonstrated that the LPS biosynthesis enzyme $\mathrm{WbcJ}$, involved in $\mathrm{O}$-antigen production in $H$. pylori, is induced at $\mathrm{pH} 4.0$ (McGowan et al., 1998). We did not detect induction of $w b c J$ in our studies, either using the array or by DNA probe hybridization to $\mathrm{pH} 4 \cdot 0 \mathrm{RNA}$ on slot-blots. The reason for this is unclear but probably reflects differences in the in vitro conditions or duration of the acid exposure. The fact that an isogenic $w b c J$ mutant shows increased sensitivity to acid stress does suggest, however, that the ability to alter the structure of LPS is an important acid survival mechanism. It is suggested that LPS may contribute to the barrier function of the outer membrane, reducing proton influx and thus promoting maintenance of a favourable periplasmic and intracellular $\mathrm{pH}$ (McGowan et al., 1998). Indeed, the phenotype of an E. coli UDP-3-O-acyl $\mathrm{N}$-acetylglucosamine deacetylase $(e n v A)$ null mutant includes increased sensitivity to antibiotics as a result of hyperpermeability (Grunstrom et al., 1980). The levels of the E. coli enzyme increase during periods of lipid A depletion, suggesting that control of expression of the deacetylase regulates the rate of lipid A biosynthesis (Sorensen et al., 1996). Although this control is exerted at the level of translation in E. coli, it is feasible that transcriptional control of UDP-3-O-acyl $\mathrm{N}$-acetylglucosamine deacetylase may regulate LPS biosynthesis in H. pylori. Given that the E. coli enzyme is required for the normal barrier function of the outer membrane and that expression of the enzyme is regulated in response to levels of lipid A, it may be that transcriptional upregulation of this enzyme in $H$. pylori is a direct response to acidic $\mathrm{pH}$ and reflects a need to maintain an effective barrier against proton influx. Indeed, any acid-induced changes in gene expression with the potential to alter the surface properties of the bacterium are of interest as these may be relevant to its ability to maintain a favourable intracellular $\mathrm{pH}$ during exposure to gastric acid. The induction of the phospholipid biosynthetic enzyme CDP-diacylglycerol pyrophosphatase at low $\mathrm{pH}$ may also reflect a need to maintain an effective membrane barrier. Induction of LPS and phospholipid biosynthetic enzymes was reported in S. enterica serovar Typhimurium following exposure to an antimicrobial protein from neutrophils (Qi et al., 1995) and perhaps represents a general response to stress conditions.

Induction of SecF may also be an adaptive response to acidic conditions. Co-overexpression of SecF and SecD in E. coli results in increased secretion efficiency, suggesting that these proteins could be up-regulated at low $\mathrm{pH}$ in $\mathrm{H}$. pylori to enhance secretion of a protective extracellular or cell envelope protein.

The identification of a ribonucleotide-modifying enzyme induced at low $\mathrm{pH}$ is also interesting as it is suggested that modified nucleotides such as pseudouridine, found clustered in or close to functionally important regions of the ribosome, may be important for regulating the activity of ribosomes (see Bjork, 1996). It is tempting to speculate that in $H$. pylori, ribosome modification resulting from increased expression of pseudouridine synthase results in an alteration in ribosome activity favouring synthesis of proteins required for survival in acid.

The identification of a $H$. pylori-specific acid-induced gene (HP0681) is particularly interesting as such genes could contribute to the unique ability of the bacterium to survive exposure to gastric acid. The association of HP0681 with a predicted Sec-dependent secreted protein is intriguing given that $s e c F$ is also acid-induced and the association between secreted proteins (e.g. CagA; Covacci et al., 1993) and virulence (Finlay \& Falkow, 1997). The studies reported here were designed to identify possible acid-responsive genes which may play a role in survival in vivo. Further studies are under way to investigate the function of HP0681 and specifically its role in survival at low $\mathrm{pH}$.

In addition to genes induced by acidic conditions, we identified three genes whose expression was decreased at $\mathrm{pH} 4.0$. Their putative translation products were a putative sugar nucleotide biosynthesis protein (HP0366), a flagellar protein (HP0753) and the HopA porin (HP0229). The significance of down-regulation of these genes requires further investigation.

In summary, we have studied H. pylori gene expression in response to an environment of low $\mathrm{pH}$ by hybridization of total RNA-derived cDNA probes to high-density genomic DNA arrays. A total of 11 acidresponsive genes were identified, including eight which showed increased expression at $\mathrm{pH} 4 \cdot 0$ compared with $\mathrm{pH} 7 \cdot 0$, and three which showed decreased expression. These genes are worthy of further study as they may be relevant to the survival and persistence of $H$. pylori in vivo.

\section{ACKNOWLEDGEMENTS}

We are grateful to Tracy Roberts and Michelle Teri-Tait for preparation of the genomic DNA array. We also thank Mike Trower for use of the facilities at Glaxo Wellcome and Dennis 
Linton for critical reading of the manuscript. This work was supported by the Medical Research Council and the Biotechnology and Biological Science Research Council, United Kingdom.

\section{REFERENCES}

Alm, R. A., Ling, L. S. L., Moir, D. T. \& 20 other authors (1999). Genomic-sequence comparison of two unrelated isolates of the human gastric pathogen Helicobacter pylori. Nature 397, 176180.

Altschul, S. F., Madden, T. L., Schaffer, A. A., Zhang, J., Zheng, Z., Miller, W. \& Lipman, D. J. (1997). Gapped BLAST and PSI-BLAST: a new generation of protein database search programs. Nucleic Acids Res 25, 3389-3402.

Bijlsma, J. J. E., Gerrits, M. M., Imamdi, R., VandenbrouckeGrauls, C. M. J. E. \& Kusters, J. G. (1998). Urease-positive, acidsensitive mutants of Helicobacter pylori: urease-independent acid resistance involved in growth at low $\mathrm{pH}$. FEMS Microbiol Lett 167, 309-313.

Bjork, G. R. (1996). Stable RNA modification. In Escherichia coli and Salmonella typhimurium: Cellular and Molecular Biology, pp. 861-886. Edited by F. C. Neidhart and others. Washington, DC: American Society for Microbiology.

Clayton, C. L., Tay, A., O’Donnell, C. \& Chalk, P. A. (1995). Elucidation of Helicobacter pylori metabolism by random genome sequencing. Gut 37 (Suppl. 1), abstract 268.

Covacci, A., Censini, S., Bugnoli, M. \& 8 other authors (1993). Molecular characterization of the $128-\mathrm{kDa}$ immunodominant antigen of Helicobacter pylori associated with cytotoxicity and duodenal ulcer. Proc Natl Acad Sci U S A 90, 5791-5795.

Exner, M. M., Doig, P., Trust, T. J. \& Hancock, R. E. W. (1995). Isolation and characterization of a family of porin proteins from Helicobacter pylori. Infect Immun 63, 1567-1572.

Finlay, B. B. \& Falkow, S. (1997). Common themes in microbial pathogenicity revisited. Microbiol Mol Biol Rev 61, 136-169.

Foster, J. W. \& Bearson, B. (1994). Acid-sensitive mutants of Salmonella typhimurium identified through a dinitrophenol lethal screening strategy. J Bacteriol 176, 2596-2602.

Grunstrom, T. S., Normark, S. \& Magnusson, K. (1980). Overproduction of outer membrane protein suppresses $e n v A$-mediated hyperpermeability. J Bacteriol 144, 884-890.

Huesca, M., Goodwin, A., Bhagwansingh, A., Hoffman, P. \& Lingwood, C. L. (1998). Characterization of an acidic-pH-inducible stress protein (hsp70), a putative sulfatide adhesin, from Helicobacter pylori. Infect Immun 66, 4061-4067.
Jungblut, P. R., Bumann, D., Haas, G., Zimny-Arndt, U., Holland, P., Lamer, S., Siejak, F., Aebischer, A. \& Meyer, T. F. (2000). Comparative proteome analysis of Helicobacter pylori. Mol Microbiol 36, 710-725.

Karita, M., Tummuru, M. K. R., Wirth, H.-P. \& Blaser, M. J. (1996). Effect of growth phase and acid shock on Helicobacter pylori cagA expression. Infect Immun 64, 4501-4507.

Kittler, J. T., Grigorenko, E. V., Clayton, C., Zhuang, S.-Y., Bundey, S. C., Trower, M. M., Wallace, D., Hampson, R. \& Deadwyler, S. (2000). Large-scale analysis of gene expression changes during acute and chronic exposure to $\Delta^{9}-\mathrm{THC}$ in rats. Physiol Genomics 3, 175-185.

Leclerc, G., Wang, S. P. \& Ely, B. (1998). A new class of Caulobacter crescentus flagellar genes. J Bacteriol 180, 5010-5019.

McGowan, C. C., Cover, T. L. \& Blaser, M. J. (1996). Helicobacter pylori and gastric acid: biological and therapeutic implications. Gastroenterology 110, 926-938.

McGowan, C. C., Necheva, A., Thompson, S. A., Cover, T. L. \& Blaser, M. J. (1998). Acid-induced expression of an LPS-associated gene in Helicobacter pylori. Mol Microbiol 30, 19-31.

Qi, S.-Y., Li, Y., Szyroki, A., Giles, I. G., Moir, A. \& O'Connor, C. D. (1995). Salmonella typhimurium responses to a bactericidal protein from human neutrophils. Mol Microbiol 17, 523-531.

Rimini, R., Jansson, B., Feger, G. \& 8 other authors (2000). Global analysis of transcription kinetics during competence development in Streptococcus pneumoniae using high density DNA arrays. Mol Microbiol 36, 1279-1292.

Sorensen, P. G., Lutkenhaus, J., Young, K., Eveland, S. S., Anderson, M. S. \& Raetz, R. H. (1996). Regulation of UDP-3-O[R-3-hydroxymyristoyl]- $N$-acetylglucosamine deacetylase in Escherichia coli - the second enzymatic step of lipid A biosynthesis. J Biol Chem 271, 25898-25905.

Thomsen, L. L., Gavin, J. B. \& Tasman-Jones, C. (1990). Relation of Helicobacter pylori to the human gastric mucosa in chronic gastritis of the antrum. Gut 31, 1230-1236.

Tomb, J. F., White, O., Kerlavage, A. R. \& 39 other authors (1997). The complete genome sequence of the gastric pathogen Helicobacter pylori. Nature 388, 539-547.

Ye, R., Wang, W. T., Bedzyk, L., Young, T., Chen, M. \& Li, L. (2000). Global gene expression profiles of Bacillus subtilis grown under anaerobic conditions. J Bacteriol 182, 4458-4465.

Received 23 April 2001; accepted 30 April 2001 